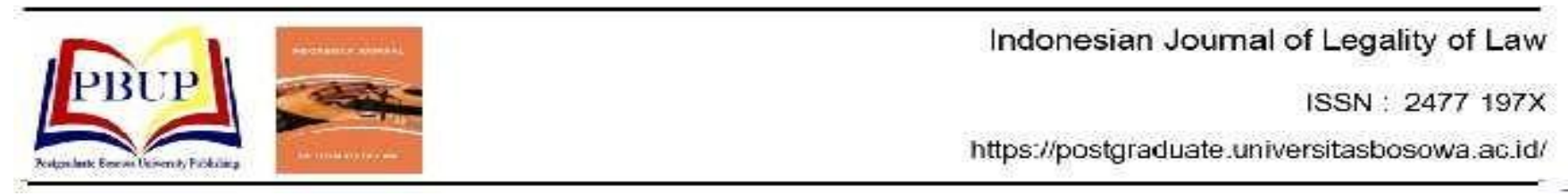

\title{
FUNGSI SIDIK JARI DALAM PENGUNGKAPAN KASUS TINDAK PIDANA PEMBUNUHAN (Studi Kasus pada Ditreskrimum Polda Sulawesi Selatan)
}

\author{
The Fingerprint Function in Disclosure of Murder Criminal Actions \\ (Case Study on the South Sulawesi Regional Police Headquarters Ditreskrimum) \\ Tri Wulandari Winda ${ }^{1}$, Ruslan Renggong ${ }^{2}$, Abdul Salam Siku ${ }^{2}$ \\ ${ }^{1}$ Mahasiswa Program Studi Ilmu Hukum Program Pascasarjana Universitas Bosowa \\ ${ }^{2}$ Prodi Ilmu Hukum Universitas Bosowa \\ Email: triwinda95@gmail.com
}

Diterima: 08 Agustus 2019/Disetujui: 09 Desember 2019

\begin{abstract}
ABSTRAK
Tujuan penelitian ini adalah untuk mengetahui fungsi sidik jari bagi penyidik dalam pengungkapan kasus tindak pidana pembunuhan dan mengetahui hambatan yang dialami oleh penyidik dalam melakukan pembuktian dengan Sidik Jari (Daktiloskopi) di Ditreskrimum Polda Sulawesi Selatan. Penelitian ini menggunakan pendekatan penelitian kualitatif, dengan pengambilan data secara purposiv sampling dengan cara menelaah dan mengkaji identifikasi sidik jari yang digunakan sebagai dasar dalam melakukan pemecahan masalah. Hasil penelitian menunjukkan bahwa fungsi sidik jari bagi penyidik dan sangat akurat dalam pengungkapan kasus tindak pidana pembunuhan dengan identifikasi dan pengamatan sidik jari dapat diketahui identitas seseorang secara detail dan jelas bagi pelaku pembunuhan karena di dunia ini tidak ada yang manusia memiliki sidik jari yang sama, sehingga sidik jari yang dimiliki pelaku dapat dijadikan pembuktian di Tempat Kejadian Perkara (TKP), tidak dalam status quo lagi atau TKP sudah dalam keadaan rusak sehingga penyidik sulit dalam mengidentifikasi sidik jari, sebagaimana yang terjadi pada kasus tindak pidana pembunuhan di Ditreskrimum Polda Sulawesi Selatan.
\end{abstract}

Kata Kunci: Sidik jari, Tindak pidana, Pembunuhan

\begin{abstract}
The purpose of this study was to determine the function of fingerprints for investigators in the disclosure of murder crime cases and find out the obstacles experienced by investigators in conducting evidence with Fingerprints (Dactyloscopy) at the Directorate of Criminal Police of South Sulawesi. This study uses a qualitative research approach, data collection by purposive sampling, by analyzing and reviewing fingerprint identification that is used as a basis for solving problems. The results showed that the fingerprint function for investigators and very accurate in the disclosure of murder crime cases by identifying and observing fingerprints can be known of a person's identity in detail and clearly for the perpetrators of murder because in this world no human being has the same fingerprint, so fingerprints owned by the perpetrators can be used as evidence at the crime scene (CS), not in the status quo anymore or the crime scene is already in a damaged condition so that investigators find it difficult to identify fingerprints, as happened in the criminal case of murder in South Sulawesi Regional Police Headquarters Ditreskrimum.
\end{abstract}

Keywords: Fingerprints, Crime, Murder

\section{PENDAHULUAN}

Kejahatan merupakan bagian dari masalah di dalam kehidupan sehari-hari, karena kejahatan dan masyarakat tidak dapat dipisahkan. Perkembangan masyarakat juga diikuti berkembangnya kejahatan, seperti teknologi maju yang dipergunakan masyarakat juga dapat dipergunakan oleh para pelaku kejahatan. Dengan kata lain bahwa kejahatan merupakan salah satu penyakit masyarakat. Dalam Pasal 338 KUHP adalah suatu rumusan tindak pidana materill (materieel delict), yakni suatu tindak pidana yang baru dapat di-anggap sebagai telah selesai pelakunya dengan timbulnya akibat yang terlarang atau tidak dikehendaki oleh Undang-Undang (Sinaga, 2018)
Dalam Undang-Undang Dasar 1945 telah dijelaskan bahwa Negara Indonesia adalah Negara berdasarkan hukum dan tidak berdasarkan kekuasaan, Negara Indonesia merupakan negara yang demokratis dan menjunjung tinggi yang berdasarkan nilai-nilai Pancasila dan Undang-Undang Dasar 1945.

Hukum merupakan norma atau kaidah yang memuat aturan-aturan yang menjamin hak dan kewajiban seseorang maupun masyarakat, dengan adanya hukum di Indonesia menciptakan keselarasan dalam hidup bermasyarakat, berbangsa, dan bernegara (Adami, 2002). Dengan perkembangan zaman berpengaruh terhadapkejahatan yang turut 
berkembang, cara-cara baru dalam melakukan kejahatan semakin sadis dan sangat memprihatinkan yang saat ini meresahkan masyarakat akan keselamatan dirinya bah-kan orang terdekatnya, dalam melancarkan aksinya pelaku sebisa mungkin mengelabui Aparat Kepolisian dengan berbagai modus yang berbeda-beda dan semakin berkembang (Bassar,1996;Amir, 2012).

Menurut Bassar, (1986), setiap pelanggaran akan dikenakan sanksi (hukuman), dalam menetapkan suatu hukum diperlukan adanya pembuktian yang wajib disampaikan di depan pengadilan. Sebagaimana kita ketahui bahwa tindak pidana pembunuhan adalah suatu tindak kejahatan merampas nyawa manusia

Dalam Undang-Undang Nomor 2 Tahun 2002 tentang kepolisian Negara Republik Indonesia, Penyidikan adalah serangkaian tindakan penyidik dalam hal dan menuntut cara yang diatur dalam Undang-Undang untuk mencari serta mengumpulkan bukti yang dengan bukti itu membuat terang tentang tindak pidana yang terjadi dan untuk menemukan tersangkanya (HaridanLily, 2003; Lamintang, 2010). Seperti pembunuhan yang dilakukan dengan cara mutilasi, memotong-motong bagian tubuh dan potongan tubuh tersebut dibuang di berbagai tempat yang berbeda untuk mengelabui polisi agar kesulitan dalam mengidentifikasi korban tersebut pada setiap sidik jari seseorang mempunyai rumus dan bentuk yang berbedabeda sehingga sidik jari seseorang membantu pihak Kepolisian dalam mengungkap identitas para pelaku lebih cepat, tepat, dan sesegera mungkin pelaku bisa tertangkap (Ledeng, 2005).

Maraknya kasus Tindak Pidana Pembunuhan bahkan sampai memutilasi korbannya, maka dengan kejadian tersebut khususnya di wilayah Sulawesi Selatan, sehingga Pihak Kepolisian memiliki alat yang dapat mengungkap identitas korban pembunuhan ataupun pelaku dengan alat dan atau benda yang kiranya digunakan pelaku untuk melakukan tindakan pembunuhan yaitu dengan menggunakan Metode Sidik Jari (Dactyloscopy) (Farid,1995; Hamzah, 2008). Fungsi sidik jari sendiri merupakan proses menganalisis struktur kerutan terhadap pelaku dan di lakukan oleh pihak kepolisian untuk mengetahui dan membedakan antara orang satu dan yang lainnya.

Pem-buktian merupakan masalah yang memegang peranan dalam proses pemeriksaan di pengadilan. Melalui pem-buktian ditentukan nasib terdakwa. Apabila hasil pem-buktian dengan alat-alat bukti yang ditentukan oleh undang-undang "tidak cukup" membuktikan kesalahan yang didakwakan kepada terdakwa, terdakwa "dibebaskan" dari hukuman. Sebaliknya, kalau terdakwa dapat dibuktikan dengan alat-alat bukti, maka terdakwa dinyatakan bersalah, kepada terdakwa akan di jatuhkan hukuman. Oleh karena itu, hakim harus berhati-hati, cermat, menilai dan mempertimbangkan nilai pembuktian.

Berdasarkan Pasal 183 Undang-undang Nomor 8 Tahun 1981 Tentang Kitab Undang-undang Hukum Acara Pidana (KUHAP) dapat disimpulkan bahwa sebelum hakim menjatuhkan pidana kepada terdakwa, maka hakim memerlukan 2 alat bukti (Prodjodikoro, 1962;UU No.8 tahun 1981). Alat bukti ini berfungsi untuk memperkuat keyakinan hakim terhadap tindak pidana yang dilakukan terdakwa khususnya terkait kasus Tindak Pidana Pembunuhan yang terjadi di Wilayah Sulawesi Selatan.

\section{METODE PENELITIAN}

Penelitian ini merupakan jenis penelitian hukum kualitatif. Penelitian hukum kualitatif berorientasi pada data yang didapat dari penjelasan narasumber, dokumendokumen dan wawancara atau bahan hukum yang berlaku dan berkaitan dengan peran sidik jari. Penelitian hukum kualitatif dilakukan dengan cara wawancara dengan narasumber Kasi Identifikasi Ditreskrimum Polda Sulsel. Fokus penelitian ini adalah tentang bagaimana metode Ilmu Sidik Jari di tingkat penyidikan dalam mengungkap tindak pidana di Ditreskrimum Polda Sulsel.

Sumber data yang di gunakan dalam penulisan ini adalah data sekunder. Data sekunder yaitu data yang bersumber dari perundang-undangan atau terdiri dari bahan hukum, baik itu bahan hukum primer, bahan hukum sekunder dan bahan hukum tersier. Bahan-bahan hukum yang mempunyai kekuatan mengikat dan terdiri dari: a.Norma atau kaidah dasar, yaitu Pembukaan UUD 1945, b. Peraturan Perundang-undangan, yaitu: KUHP dan KUHAP, dan Bahan Hukum Sekunder, untuk memberikan penjelasan mengenai bahan hukum primer (buku ilmu hukum, jurnal hukum, laporan hukum, dan media cetak atau elektronik), serta Bahan Hukum Tersier yaitu Bahanbahan yang memberikan penjelasan terhadap bahan hukum primer dan skunder, misalnya: kamus-kamus hukum, ensiklopedia dan sebagainya.

Teknik Pengumpulan data yang digunakan penulis ada dua cara yaitu: Teknik Wawancara, dimana peneliti datang langsung dan melakukan Tanya jawab langsung dimana semua pernyataan disusun secara sistematis dan terarah sesuai dengan isu hukum yang diangkat dalam penelitian. Wawancara langsung ini dimaksudkan untuk memperoleh informasi yang benar dan akurat dari sumber yang ditetapkan sebeumnya.

Teknik Studi Dokumen, yaitu membaca serta mengkaji bahan-bahan bacaan seperti undang-undang, peraturan-peraturan, majalah-majalah, dan makalah serta buku-buku yang berkaitan dengan relevan dengan pembahasan ini.

\section{HASIL DAN PEMBAHASAN}

\subsection{Fungsi Sidik Jari Dalam Pengungkapan Tindak Pi- dana Pembunuhan Di Wilayah Hukum Polda Sulsel}

Direktorat Reserse Kriminal Umum Polda Sulsel dalam upaya mengungkap tindak pidana pembunuhan yang terjadi dimasyarakat Provinsi Sulawesi Selatan terlebih dahulu dilakukan adalah melakukan penyelidikan dan penyidikan berdasarkan laporan atau pengaduan. Laporan menurut Pasal 1 butir KUHAP adalah pemberitahuan yang disampaikan oleh seseorang karena hak atau kewajiban berdasarkan undang-undang kepada pejabat yang berwenang tentang telah atau sedang atau diduga akan terjadinya peristiwa pidana. Sedangkan pengaduan menurut pasal 1 butir 25 menurut KUHAP adalah pemberitahuan disertai permintaan oleh pihak yang berkepentingan kepada pejabat yang berwenang untuk menindak menurut hukum seorang yang telah melakukan tindak pidana aduan yang merugikannya.

Disamping adanya laporan dan pengaduan dapat pula terjadi tersangka tertangkap tangan. Dalam hal tersangka tertangkap tangan, maka tidak diperlukannya adanya laporan atau aduan terlebih dahulu. Sebagaimana diatur dalam pasal 15 ayat (1) butir (a) Unadang-undang Kepolisian Republik Indonesia Nomor 02 Tahun 2002, yaitu dalam 
melaksanakan tugasnya penyidik mempunyai wewenang laporan menerima dan atau pengaduan.

Tindak pidana pembunuhan termasuk salah satu delik formil yang menekankan pada perbuatan yang dilarang oleh suatu aturan hukum, larangan yang disertai ancaman atau sanksi yang berupa pidana tertentu bagi barang siapa yang melanggar larangan tersebut atau pelaku yang melakukan perbuatan pidana sehingga pelakunya harus dimintakan pertanggungjawaban atas perbuatan pidana yang dilakukannya, untuk menentukan siapa pelaku tindak pidana pembunuhan diperlukan pembuktian sebagaimana diataur dalam Pasal 183 dan Pasal 184 Kitab UndangUndang Hukum Acara Pidana (KUHAP), sehingga pencarian bukti-bukti awal sangat penting dan berguna untuk menemukan pelakunya. Oleh karena itu diperlukan kejelian kepolisian untuk mencari bukti-bukti awal dengan cara mengumpulkan data-data dari bekas peristiwa pembunuhan dengan jalan mendatangi tempat kejadian perkara dan mengambil sidik jari.

Sebagaimana diatur dalam Undang-undang Nomor 2 Tahun 2002 tentang Kepolisian Negara Republik Indonesia, disebutkan dalam pasal 14 ayat (1) butir (g) "melakukan penyelidikan dan penyidikan terhadap semua tindak pidana sesuai hukum acara pidana dan peraturan perundang-undangan lainnya, dan didalam pasal 15 ayat (1) butir (h)" mengambil sidik jari dan identitas lainnya serta memotret seseorang". Berdasarkan keterangan diatas dapat dilihat bahwa penyidik berwenang mengambil sidik jari untuk kepentingan penyidikan dalam mengungkap tindak pidana pembunuhan.

Adapun langkah-langkah penyidik dalam upaya melakukan proses penyidikan tindak pidana pembunuhan salah satunya yaitu dengan menggunakan bukti awal sidik jari, apabila pelaku dalam melakukan perbuatan tindak pidana pembunuhan meninggalkan jejak berupa sidik jari hal tersebut dilakukan penyidik memulai dengan mendatangi tempat kejadian perkara, memeriksa bagaimana cara pelaku masuk dan keluar dari tempat kejadian perkara, memeriksa apa yang dilakukan oleh tersangka, melakukan pemotretan dan pembuatan sketsa, mencari alat-alat bukti yang tertinggal terutama alat bukti fisik seperti bekasbekas sidik jari yang dimungkinkan pada alat tersebut. Setelah penyidik menemukan sidik jari ditempat kejadian perkara selanjutnya penyidik mencocokkan atau membandingkan sidik jari yang ditemukan dengan sidik jari saksi atau tersangka dan atau data yang dimiliki dibagian identifikasi.

Selanjutnya penyidik melakukan proses penyidikan dengan melakukan pemeriksaan saksi atau korban serta menangkap tersangka, melengkapi berkas perkara sampai dengan penyerahan berkas perkara serta limpah tersangka dan barang bukti apabila ada barang bukti kepada penuntut umum atau Kejaksaan. Adapun langkah-langkah penangkapan tindak pidana pembunuhan dengan menggunakan sidik jari yang ditemukan ditempat kejadian perkara adalah mencari sidik jari tempat kejadian perkara

Ditempat kejadian perkara sering tertinggal bekasbekas pelaku tindak pidana, yang satu diantaranya adalah sidik jari. Suatu ungkapan yang telah terbukti bahwa penjahat dalam melakukan operasinya sering membuat suatu kesalahan. Sidik jari yang tertinggal di tempat kejadian perkara yang terjenal dengan istilah "latent finger print" dapat digunakan sebagai petunjuk untuk pengenalan kembali pelaku tindak pidana disamping bukti-bukti lainnya. Kasi Indentifikasi Ditreskrimum Polda Sulsel Kompol Ali Muchtar menambahkan bahwa langkah-langkah yang dilakukan unit Identifikasi dalam mengambil sidik jari untuk mengungkap perkara tindak pidana pembunuhan di Wilayah hukum Polda Sulsel adalah sebagai berikut: 1) Petugas identifikasi bersama-sama dengan petugas yang lain turut serta mendatangi tempat kejadian perkara. Saat sampai di tempat kejadian perkara kemudian mencari bukti-bukti yang ditinggalkan, memotret tempat kejadian perkara secara umum dari berbagai sudut dan selanjutnya melakukan proses olah tempat kejadian perkara untuk mengetahui bagaimana pelaku melakukan tindak pidana, dengan apa pelaku melakukan tindak pidana itu dan kemudian mencari tahu siapa pelaku tindak pidana tersebut, b.) Mencari benda-benda yang berada ditempat kejadian perkara yang kemungkinan dipegang oleh pelaku misalnya :1) tempat atau jalan pelaku masuk atau keluar seperti handel atau gagang pintu, kaca dan jendela, 2) benda atau objek yang dirusak, 3). benda-benda yang dipegang atau dipindahkan pelaku, 4. alat-alat yang digunakan untuk membongkar, baik yang tertinggal di tempat kejadian perkara atau ditemukan kemudian, dan 5. pakaian milik korban.

Setelah ditemukan sidik jari kemudian sidik jari tersebut diambil dengan cara-cara sesuai keadaan sidik jari yang ditemukan. Apabila sidik jari yang ditemukan adalah sidik jari yang sudah nampak dengan terang/nyata disebabkan karena perpindahan beberapa zat warna kepada benda yang lain dengan perantaraan jari-jari. Sidik jari yang demikian ini dapat lekas kita ketahui pada semua benda yang bersifat padat. Karena sidik jari ini berwarna maka selain mudah dapat diketahui, memotretnya juga mudah. Sedangkan sidik jari yang tidak nampak dengan nyata (latent) sukar sekali untuk diketahui dan dikenal apabila ditempat-tempat yang tidak terang. Untuk sidik jari ini dibutuhkan perhatian yang seksama.

Berdasarkan uraian tersebut dapat penulis analisis dan pahami bahwa sidik jari yang telah diambil dari tempat kejadian pencurian selanjutnya di lihat rmusnya dan kemudian di cocokkan dengan data yang ada di Sie Identifikasi Ditreskrimum Polda Sulsel, apabila sidik jari yang ditemukan identic dengan data yang ada di Polda maka bisa ditarik kesimpulan awal bahwa pelaku kejahatan tersebut telah diketahui identitasnya sehingga sidik jari yang dapat tersebut bisa dijadikan petunjuk dalam pengungkapan pelaku tindak pidana pencurian yang terjadi guna proses penyidikan dengan di tambah dengan alat bukti lain.

\subsection{Kendala yang dihadapi dalam pengungkapan tindak pidana dengan menggunakan sidik jari di Ditreskrimum Polda Sulawesi Selatan}

Kendala penggunaan sidik jari dalam proses penyelidikan dan penyidikan yang dilakukan Kepolisian merupakan bagian yang penting dan strategi dari upaya penegakan hukum secara menyeluruh. Ditreskrimum Polda Sulsel dalam upaya mengungkap kasus tindak pidana pem-bunuhan yang dilakukan oleh seseorang yang tidak ada bukti yang jelas, misalnya si pelaku tersebut dalam mela-kukan tindak pidana tidak tertangkap tangan atau tidak ada saksi atau bukti lain, sehingga Polisi atau penyidik kesu-litan dalam 
membuktikaan kebenaran persangkaanya terhadap seseorang bahwa orang tersebut melakukan tindak pidana, maka sidik jari tersangka yang menempel pada benda yang terdapat di tempat kejadian perkara atau benda milik korban yang diduga oleh penyidik bahwa benda-benda itu telah penuh dipegang oleh tersangka, merupakan bukti yang penting untuk mengungkap kejahatan tersebut.

Kasi Identifikasi Ditreskrimum Polda Sulsel, menyatakan bahwa seharusnya setiap Polsek memiliki minimal 2 (dua) orang personil reserse kriminal di bagian identifikasi yang professional sehingga dalam pelaksanaan tugas identifikasi apabila terjadi tindak pidana pembunuhan di wilayah Polres dan Polsek jajaran Polda Sulsel bisa ditangani oleh petugas identifikasi dari Polsek tidak lagi menunggu petugas identifikasi dari Polda Sulsel sehingga pelaksanaan tugas dapat berjalan dengan cepat dan diharapkan pengungkapan perkara juga lebih cepat. Keku-rangan personil identifikasi tersebut juga merupakan ham-batan pelaksanaan tugas pengungkapan perkara tindak pidana, selengkapnya Kasi Identifikasi mengatakan seba-gai berikut: "Sampai saat ini jumlah personil identifikasi Polda Sulsel masih sangat sedikit, terutama dikaitkan dengan luasnya wilayah dan tingginya perkara tindak pidana pembunuhan yang terjadi, sehingga pelaksanaan tugas identifikasi terutama dalam pengambilan sidik jari penanganannya kurang cepat dan kurang optimal karena terbatasnya personil dibidang identifikasi, sehingga diperlukan minimal setiap Polsek Jajaran Polda Sulsel memiliki 2 (dua) personil identifikasi yang membidangi sidik jari."

Berdasarkan keterangan dan fakta tersebut diatas, kiranya dapat ditarik pengertian bahwa salah satu kesulitan utama yang dialami oleh Bagian Identifikasi Polda Sulsel jajaran dalam mengambil sidik jari di tempat kejadian perkara untuk mengungkap pelaku tindak pidana pembunuhan adalah terbatasnya jumlah personil.

Kemudian kendala Aturan, Sarana dan Prasarana. Mengingat jumlah sidik jari yang didapat akan sangat banyak jumlahnya yaitu dari seluruh warga dengan batas umur tertentu, dimana didalam pelaksanaan perumusan serta penyimpanan kartu sidik jari harus diketahui atau diakui oleh petugas, agar tidak sulit untuk mencari kembali dengan relative cepat dalam arti siap pakai untuk segala kebutuhan. Sedangkan manusia adalah makhluk yang tidak luput dari kesalahan, kejenuhan dan kebosanan sehingga kartu sidik jari yang ada tidak lagi dari sekedar tumpukan kertas yang tidak ada nilainya. Hal ini merupakan hambatan dari tugas Kepolisisan (membantu tugas penyidikan dalam mengenal pelaku tindak pidana).

Dari dasar hukum yang ada sekarang ini, masih dirasakan kekurangan terhadap pelaksanaan tugas kepolisian untuk mengambil sidik jari semua penduduk Indonesia atau dengan kata lain belum adanya peraturan yang mengharuskan setiap warga Negara Indonesia termasuk orang asing yang bertempat tinggal di Indonesia dengan batas umur tertentu untuk diambil sidik jarinya. Hal ini jelas Merupakan faktor yang menghambat penyimpanan sidik jari yang terpusat sebagai upaya bantu dalam pengenalan pelaku tindak pidana. Kurang lengkapnya alat (peralatan) yang dimiliki Polres-Polres jajaran Polda Sulsel, disamping itu alat yang ada masih terlalu sedikit, sedangkan tingkat dan jumlah kriminalitas semakin lama cenderung semakin meningkat bahwa modus operandinya semakin lama semakin canggih.
Kendala tersebut dapat penulis analis bahwa dalam kerjasama dengan pemerintah belum berjalan baik karena belum semua masyarakat yang mempunyai KTP elektronik sehingga dapat menghambat pencarian data pelaku sehingga hal tersebut merupakan hambatan dalam percepatan pengungkapan tindak pidana pembunuhan yang terjadi di wilayah hukum Polda Sulsel. Kendala Kultur Budaya Masyarakat Menurut Kasi Identifikasi Ditreskrimum Polda Sulsel disebutkan bahwa pada saat sekarang ini pengetahuan masyarakat tentang arti sidik jari, sangat kurang sekali sehingga tidak mengetahui apa sesungguhnya kegunaan dari sidik jari itu. Hal ini terlihat dari tempat kejadian perkara yang sering kali berubah karena jika terdapat laporan tentang terjadinya suatu tindak pidana, petugas penyidik yang datang ke tempat kejadian perkara sering menjumpai tempat kejadian perkara telah berubah (tidak dalam keadaan aslinya ketika peristiwa terjadi). Hal ini akan menyulitkan bagi petugas, baik dalam hal mengumpulkan barang-barang bukti maupun dalam menilai atau menganalisa peristiwa yang terjadi.

Keaslian tempat kejadian adalah sangat penting, sebab bekas-bekas tindak pidana yang terdapat di tempat kejadian perkara tersebut dapat ditarik suatu gambaran tentang kejadian yang sebenarnya serta memudahkan penyidikannya selanjutnya. Jika tempat kejadian telah berubah, terutama didalam usaha pencarian bekas-bekas sidik jari pelaku tindak pidana adalah amat sulit, sebab kemungkinan dapat hilang karena sentuhan/injak dari orang-orang yang tidak berkepentingan untuk menyidik misalnya keluarga/ tetangga korban yang telah datang terlebih dahulu di Tempat Kejadian Perkara. Seandainya bekas-bekas sidik jari itu tidak sampai hilang akan mempercepat proses penyidikan, tetapi seringkali ditemui adanya bekas-bekas sidik jari yang terbentuk dan bercampur dengan bekasbekas sidik jari pelaku tindak pidana. Hal ini agak menyulitkan petugas untuk mengidentifikasi seseorang. Hal sesuai dengan pernyataan Napitupulu, (2019), bahwa kepolisian Negara Republik Indonesia dalam menjalankan tugasnya sebagai aparat penegak hukum, sering mengalami beberapa permasalahan, salah satunya ialah terkait hilangnya sejumlah barang dari TKP yang telah dipasang "police line" oleh penyidik.

Berdasarkan keadaan yang demikian dapat disimpulkan bahwa sebagian masyarakat masih belum mengerti betapa pentingnya keaslian dari tempat kejadian perkara sebagai tindak lanjut penyidikan kepolisian, dimana dengan terdapat bekas-bekas sidik jari yang dapat diketahui identitas tersangka sehingga akan dapat mengungkap tindak pidana yang terjadi. Hal tersebut dapat menghambat dalam hal pengambilan sidik jari ditempat kejadian perkara karena kondisi sudah tidak asli lagi dengan kata lain sudah tercampur sidik jari orang yang masuk terlebih dahulu ke tempat kejadian perkara dari pada penyidik sehingga mempersulit penyidik untuk menentukan sidik jari mana yang mau diambil.

\section{KESIMPULAN}

Sesuai dengan pembahasan dan penelitian di lapangan maka, maka dapat disimpulkan bahwa Polisi dalam mengungkap tindak pidana pembunuhan, untuk mencari siapa pelakunya, polisi menjadikan sidik jari sebagai salah satu alat bukti untuk mengungkap atau mencari siapa pelakunya. Karena sidik jari merupakan alat bukti utama untuk meng- 
ungkap kasus tindak pidana pembunuhan, yang mana sidik jari tidak dapat dimanipulasi atau berbohong seperti keterangan saksi yang biasa saja dapat berbohong, karena sidik jari manusia yang satu dengan yang lain mempunyai bentuk bentuk yang berbeda-beda dan sangat akurat dalam meng-ungkap siapa pelakunya.

\section{DAFTAR PUSTAKA}

Adami Chazawi, (2002). Pelajaran Hukum Pidana (Stelsel Pidana, Tindak Pidana, Teori-Teori Pemidanaan \& Batas Berlakunya Hukum Pidana), Bagian 1, Jakarta: PT. Raja Grafindo Persada.

Amir Ilyas, (2012). Asas-asas Hukum Pidana, Rangkang Education. Yogyakarta:Yogyakarta \& PuKAPIndonesia

Andi Zainal Abidin Farid, 1995. Hukum Pidana I, Jakarta: Sinar Grafika.

Andi Hamzah, (2008). Asas-Asas Hukum Pidana, Jakarta: Rineka Cipta.

Bassar, M. Sudrajat, (1986). Tindak-Tindak Pidana Tertentu di dalam Kitab Undang-Undang Hukum Pidana, Bandung: Remadja Karya.

Hari Sasangka dan Lily Rosita (2003). Hukum Pembuktian Dalam Perkara Pidana,Mandar Maju, Bandung.

Lamintang, (2010). Kejahatan Terhadap Nyawa, Tubuh, Dan Kesehatan, Jakarta : Sinar Grafika, 2010.

Leden Marpaung, (2005). Tindak Pidana Terhadap Nyawa dan Tubuh, Cetakan Ke-3, Jakarta: Sinar Grafika.

Napitupulu, R. (2019). Pertanggungjawaban Hukum PenyidikAtas Hilangnya Barang Dari TKP Yang Telah Dipasang police Line (Studi Kasus Putusan Pengadilan Negeri Medan Nomor 52Pdt. G2015P) (Doctoral dissertation).

Undang-undang, No. 8 tahun 1981 tentang Hukum Acara Pidana, LN. Nomor 8 Tahun 2004, TLN.Nomor 4358.

Sinaga, M. I. (2018). Peranan Uji Balistik Dalam Pembuktian Tindak Pidana Pembunuhan Dengan Menggunakan Senjata Api (Studi di Laboraturium Forensik Polri Cabang Medan) (Doctoral dissertation) 